\title{
Woman Language in a Political Campaign for the Region General Election: Khofifah Indar Parawansa
}

\section{S. Suciati1, Rustono², T. Supriyanto², and M. Mulyani²}

${ }^{1}$ Indonesian Language and Literature Education, Faculty of Language and Art Education, Universitas PGRI Semarang, Jalan Sidodadi Timur 24 Semarang 50232, Central Java Indonesia ${ }^{2}$ Indonesian Language and Literature Education, Faculty of Language and Art, Universitas Negeri Semarang, Jalan Sekaran, Semarang 50229, Central Java Indonesia

\section{Abstract}

Based on the campaign speech of a candidate for governor of East Java, a woman namely Khofifah Indar Parawansa, 3 important features related to the language emerged. First, masculine language dominates the selection of words and expressions in the delivery of aims and intentions. Second, the masculinization of language usage

Corresponding Author:

S. Suciati

srisuciati@upgris.ac.id

Received: 6 April 2018

Accepted: 3 May 2018

Published: 26 July 2018

Publishing services provided by Knowledge E

(c) S. Suciati et al. This article is distributed under the terms of the Creative Commons

Attribution License, which permits unrestricted use and redistribution provided that the original author and source are credited.

Selection and Peer-review under the responsibility of the ISLLE 2017 Conference Committee. in Khofifah's campaign speech represents her as an intelligent, courageous, and brave character. Third, the masculine aspect of language usage breaks down the feminine tradition that has been recognized as a female stereotype. Surprisingly, the general public is still very comfortable with the stereotypization tradition of female femininity, including in terms of language.

Keywords: campaign speeches, election, women's language

\section{Introduction}

Men and women use language differently. Variations in the choice of vocabulary, grammatical patterns, and prosodic means are sufficiently distinct to speak of male and female speech styles. The existence of the two speech styles is a linguistic reflection of social relations: until recently men have exercised more power in society. This tendency is still rather strong. Men's verbal behavior is more aggressive, as it is supposed to demonstrate a position of dominance [1]. Women were assigned a submissive role both in the workplace and at home; this accounts for more co-operative and less aggressive female speech strategies. Further, there are differences between men and women in degree or type of imitation [2]. The study of gender language is thus mainly concerned with how gender affects the ways people use language [3].

As women begin to come to the professions in greater numbers, there are pressures to adapt to a range of linguistic norms. These require them to be deferential and 
unassertive through a variety of linguistics variables reflective of women's position in society [4]. Women rarely act "like women" to achieve power and influence in politics. Women aspiring toward political leadership are more often expected to adopt masculine styles of behavior in order to get their points across.

This paper analyzed the language features used by Khofifah Indar Parawansa in her campaign speech as the candidate of regional head in the East Java election of 2013. This analysis considers differences in the language of women and men that impact word choice in her expression of both intentions and goals.

\section{Methods}

Gender studies became a widespread trend in the second part of the 2oth century as a reaction to the first wave of feminism, when for the first time ever women demanded suffrage rights. Despite the long path of this concept to its modern representation, the first view of the subject was based within a biological framework. This "biological" term was driven by the typical vision of women's position in the society. It was thought that women could not participate in social life because of their nature: their brain could not function like men's. That judgment was not scientifically motivated but was a part of a whole epoch. When gender studies came into existence, the global point of view on gender nature moved from biological to social. Today perceptions of women are confirmed by the World Health Organization; there are many researchers on whom we rely. Among those, Lakoff deals with political correctness and public apologies, focusing great attention on the peculiarities of women's speech [5].

There are two gender language styles, considered rhetorical tools, that are used by men and women to achieve certain objectives. The first gender language style, called masculine language, is commanding and instrumental. Masculine language is generally considered conducive to politics. The second gender language style is feminine language; it is described as intimate and unifying. Moreover, feminine language is considered too passive for the public sector altogether; still, it has become a rhetorical tool to achieve many objectives in politics [6].

For the purposes of this paper we first analyzed distinctions between male and female language in general. Then we considered these differences within the political arena and analyzed how such transformations can be represented in media discourse. Following that we analyzed extracts from a political speech of Khofifah Indar Parawansa. 
Next, we looked at phrases and words from the speech in light of general male and female peculiarities which directly supported the image of Khofifah Indar Parawansa as a woman-politician. Finally, we identified which gender strategy prevails in Khofifah's image construction. The image construction in this paper implicates not all the techniques politicians use; rather we consider only those specific phrases and words which can influence people's perception of a politician.

In giving a speech (or even just so-called public speaking), the two genders exploit language and speech for two different purposes. From a man's point of view, a speech is given for the purpose of maintaining influence over the audience, achieving status and making an arrangement. On the other hand, when women give a speech to an audience, they choose language appropriate for meeting goals such as. establishing communication, maintaining relationships and "to be liked" [7]. Nevertheless, the political context assumes that communication and language, in the frames of state management, have two very significant and critical main goals: influence and persuasion as well as communication and attraction. Because of this, it is very important for us to do research aimed at identifying distinguishing features in women's and men's language. In so doing, we can understand if there are any differences in the language structure of the two genders, or if we have differentials only in the targets.

The first distinction is in the use of adjectives. The majority of gender researchers give much attention to this word type in the speech of the two genders; differences between them have been repeatedly corroborated by experiments [5]. A woman makes use of adjectives more frequently than men and always emotionally. In contrast, politicians will be regarded as using masculine features in their speech if they employ many neutral adjectives.

Lakoff uses the word "empty" for describing language styles. Women often express themselves using empty adjectives, for example, "pretty", "cool", "divine", "precious", "lovely" and "cute" [5]. On the other hand, neutral adjectives that are considered masculine are "great", "terrific", "good", "cool", etc. The next features of masculine language are the use of simple grammar and often rude speech, direct questions or affirmative construction and, as well, less modal forms. Moreover, politicians will be considered masculine if they are able to select words, phrases, or even sentences that tend toward slang, profanity and obsenity, and to talk about sports, money, business, and economics. The use of personal nomination, and the capacity to use references to quantity, are also regarded as masculine. The next features of masculine language are the use of judgmental adjectives, directives, elliptical sentences and locatives. Besides that, the frequencies of using first-person plural words-more than the non ones-is 
also considered to characterize a politician as masculine. The last features in which we can identify whether a politician is using masculine or feminime language can be seen from the use of articles, prepositions, anger words, big words and swear words. All these are considered characteristic of masculine language [8-10].

On the other hand, people, speakers or even politicians will be regarded as feminine if they use a high frequency of emotional or empty adjectives, clear grammar and lofty lexicon and more standard speech forms. Using a lot of tag questions, more epistemic modal forms are also the features of feminine language. If a person tends to talk more about home and family and to be more emotional and positively evaluative, it can be concluded that his or her language is dominated by feminine features. Furthermore, the use of indirect nomination, intensive adverbs, emotion references, sentence-initial adverbs, dependent clauses, uncertainty verbs, negations, hedges and longer sentences are all characteristic of feminine language. The use of emotion words, cognitive mechanisms and tentative utterances are feminine aspects of language in the delivery of a speech in front of the public [8-10].

\section{Results}

Male politicians have been adding more feminine words, phrases, and themes to speeches as their campaigns have progressed, possibly for the benefit of the female electorate. If men make use of feminine flourishes, they have two purposes. First, they will be admired for being tough, and yet people like them. Women, on the other hand, risk being pegged as too aggressive if they adopt masculine phrasing [11].

The dominant use of languge, as delivered by Khofifah Indar Parawansa in her speech, contains more masculine than feminine features. From the analysis of her speech across the political campaign of 2013, it is found that she used both two kinds of language features, feminine and masculine. From the analysis also, it is seen that she used masculine features of language more than feminine language. From this finding, it can be concluded that the masculine aspects of her language break down traditional female stereotypes. Surprisingly, the general public is still very comfortable with the stereotypization tradition of female femininity, including in terms of language.

The result of the analysis shows that Khofifah Indar Parawansa used 6 adjectives of distant or neutral adjectives such as "good health", "healthy wallet", "physical health", etc. On the other hand, she did not use frequent, emotional, empty adjectives-that is, feminine language features-at all in her speech. In the next analysis, it can be seen that she used 7 direct questions or affirmative constructions (masculine features of 
language), and only 1 tag question (as a feminime language feature). It is said that the use of fewer modal forms will show masculine aspects of language; this has been done by Khofifah, as she only used 6 modal forms in her political speech.

In her speech, Khofifah also used more masculine features of language, as it is dominated by business and economics topics. She did not talk at all about topics related to home and family, and she was not more emotional and positively evaluative. The next analysis shows that she used 3 nominal nominations and o indirect nominations, thus reflecting more masculine features in her political speech. Moreover, she used 7 directives and o sentence-initial adverbs; this gives more confirmation of her use of masculine language features. The lack of feminine features of language is also shown from the use of 3 elliptical sentences compared to the use of only 1 dependent clause.

The next masculine features of language used by Khofifah Indar Parawansa are locatives or location markers in most of her political speech. It seen that she used 13 first-personal plural words; these are masculine language aspects. She also used more pronouns of non-first-person plural words (15 pronouns in total), these language features are considered masculine.

The next findings are that Khofifah Indar Parawansa still employed some features of feminine language such as the use of 34 auxiliary verbs and adverbs, 6 social references, 1 tentative word, and 1 cognitive mechanism. But she does not use emotion words, as are displayed in feminine language, at all. On the other hand, masculine features seen in her politician speech are 39 articles, 32 prepositions, 4 anger words, 6 big words. But she does not mention swear words in her political speech at all; this indicates that she is an elegant and professional politician.

From the result of the above analysis, it can be seen that there are three important qualities related to the language used in Khofifah Indar Parawansa's speeches, as delivered during her 2013 political campaign. First, masculine language dominates the selection of words and expressions in the delivery of aims and intentions. Second, the masculinization of language usage in Khofifah's speech represents her as an intelligent, courageous, and brave character. Third, the masculine look in her language usage is able to show that the feminine tradition has been recognized as a female stereotype. But-to our surprise-the general public, our society, is still very comfortable with the stereotypization tradition of female femininity. This includes speech in which the use of masculine language features is often regarded as an act of being aggresive. 


\section{Conclusion}

Every person, when giving public speeches, will show their gender frames. One thing to remember is that those frames will change in the political context. The changes of gender frames occur as a result of politicians adjusting their behavior according to a desired image: they hope to be liked and to effect a bigger and wider change in the electorate. The most important part of image construction are media sources; these are the tools by which the politician can garner sympathy from the audience and increase likeability [8]. Because of this, it is important to define what gender strategy of representation is used to form the public representation of Khofifah Indar Parawansa. In the texts about Khofifah Indar Parawansa's political speech in her campaign it is seen that she used 6 neutral adjectives, 7 direct questions, only 6 modal forms; $80 \%$ of the sentences are dominated with economics topics, 3 personal nominations, 7 directives, 2 elliptical sentences, 3 locatives, 13 first-person plural words, 39 articles, 32 prepositions, 4 anger words and 6 big words. The selection of Khofifah's words, phrases and sentences are mostly from the "masculine" group. At the same time we found 1 tag question, 6 modal forms, 1 dependent clause, 6 negations, 15 pronouns that are nonfirst-person plural words, 34 auxiliary verbs and verbs that are considered feminine, 6 social references, and 1 cognitive mechanism. From these findings of dominant features of language, it can be concluded that Khofifah Indar Parawansa was represented mostly as a masculine politician. We also defined her political image as a politician who is professional. Further, from the selective masculine features of her speech, she is also regarded as a politician who is an aggressor and at the same time also a politician who is a woman. Moreover, we saw the overrepresentation of traditionally men's features over the image of a woman. In a greater degree, then, Khofifah Indar Paranwansa has a masculine image. We may say thus she is a professional politician over other female politicians.

\section{Acknowledgement}

Authors would like to thank University of PGRI Semarang and Semarang State University for facilitated this research.

\section{Conflict of Interest}

Authors declare that there is no conflict of interest in this research. 


\section{References}

[1] Zhang Y]: Gender identity and language usages in masculine-feminine discourse. GSTF Int J Law Soc Sci. 2012; 2(1): 201-208.

[2] Black KA: Men Imitate Women, and Women Imitate Men - the Effect of Gender, Emotion, and Acoustics on Speech Imitation. Accoustic Society of America. 161st Lay Language Papers. Washington. 2011.

[3] Ma W, Wang X: On the Trend of Convergence in Gender and Political Speech under the Perspective of Performance Theory; A Case Study on 2008 President Election Candidates of USA. International Conference on Education, Language, Art and Intercultural Communicatin (ICELAIC). Published by Atlantis Press. 2014; 307311.

[4] Michael AS, Chone LS, Muthusamy C, Veeravagu J: Gendered-linked differences in speech styles: analysing linguistic and gender in the Malaysian context. Cross-Cult Commun. 2010; 6(1): 18-28.

[5] Lakoff R: Language and Woman's Place: Text and Commentaries. Oxford: Oxford University Press. 2004.

[6] Larner LR: The Role of Feminine Rhethoric in Male Presidential Discourse: Achieving Speech Purpose. CUREJ - Coll Undergrad Res Elect J. 2009.

[7] Tannen D: Gender and Discourse. Oxford: Oxford University Press. 1994.

[8] Baikalova SN: Gender Features in Female Political Discourse; The Construction of Hillary Clinton's Political Image. Journal of Siberian Federal University. Human Soc Sci. 2016; 1-9.

[9] Wood JT: "Gender." 21st Century Communication: A Reference Handbook. Ed. Thousand Oaks, CA: SAGE. 2009.

[10] Xia X: Gender Differences in Using Language. Theory Pract Lang Stud. 2013; 3(8): 1485-1489.

[11] Cauterucci C: Donald Trump Sounds More Feminime Than Any Candidate Besides Hillary Clinton. The XX Factor What Women Really Think. 2016. http://www.slate.com/blogs/xx_factor/2016/03/14/donald_trump_sounds_more _feminine_than_any_candidate_besides_hillary_clinton.html 